\title{
The Influence of Dietary Intervention in Connective Tissue Diseases: Evidence from Randomized Clinical Trials
}

\author{
Francesca Oliviero $^{1, * \mathbb{D}}$, Paola Galozzi ${ }^{1} \mathbb{D}$, Elisabetta Zanatta ${ }^{1} \mathbb{D}$, Mariele Gatto ${ }^{1}$, Paolo Spinella ${ }^{2}$ \\ and Andrea Doria ${ }^{1}(\mathbb{D}$ \\ 1 Rheumatology Unit, Department of Medicine-DIMED, University of Padova, 35128 Padova, Italy; \\ paola.galozzi@unipd.it (P.G.); elisabettazanatta86@gmail.com (E.Z.); mariele.gatto@unipd.it (M.G.); \\ adoria@unipd.it (A.D.) \\ 2 Clinical Nutrition Unit, Department of Medicine-DIMED, University of Padova, 35128 Padova, Italy; \\ paolo.spinella@unipd.it \\ * Correspondence: Francesca.oliviero@unipd.it
}

check for updates

Citation: Oliviero, F.; Galozzi, P.; Zanatta, E.; Gatto, M.; Spinella, P.; Doria, A. The Influence of Dietary Intervention in Connective Tissue Diseases: Evidence from Randomized Clinical Trials. Rheumato 2021, 1, 5-16. https://doi.org/10.3390/ rheumato1010003

Academic Editor: Bruce M. Rothschild

Received: 25 October 2021 Accepted: 16 November 2021 Published: 29 November 2021

Publisher's Note: MDPI stays neutral with regard to jurisdictional claims in published maps and institutional affiliations.

Copyright: (c) 2021 by the authors. Licensee MDPI, Basel, Switzerland. This article is an open access article distributed under the terms and conditions of the Creative Commons Attribution (CC BY) license (https:// creativecommons.org/licenses/by/ $4.0 /)$.

\begin{abstract}
The aim of this review is to identify and discuss randomized clinical trials conducted in patients with connective tissue diseases, including systemic lupus erythematosus, idiopathic inflammatory myopathies, vasculitis, Sjögren's syndrome, and systemic sclerosis. Although limited, the results obtained with bioactive compounds, namely n-3 polyunsaturated and short-chain fatty acids, demonstrate that dietary intervention and nutritional counseling might have an important role as adjuvant therapy in patients with connective tissue diseases, particularly in the light of the comorbidities which characterize these conditions.
\end{abstract}

Keywords: dietary intervention; autoimmunity; inflammation; connective tissue diseases; systemic lupus erythematosus; idiopathic inflammatory myopathies; vasculitis; Sjögren's syndrome; systemic sclerosis

\section{Introduction}

Nutritional status and dietary intake have long been recognized to affect health and disease. Increasing evidence shows how nutrient and non-nutrient (i.e., bioactive) compounds, which are being more frequently used according to a dietary lifestyle, are capable to modify disease risk factors, genetic and epigenetic pathways, inflammatory mediators and, therefore, clinical outcomes.

With respect to rheumatic diseases, much work has been conducted in an attempt understand the pathogenic molecular mechanisms that can be affected by specific dietary substances. However, despite the encouraging experimental results, clinical studies evaluating their effect on disease activity or progression are still limited and mostly regard rheumatoid arthritis. The aim of this review is to identify and discuss randomized clinical trials (RCTs) conducted on autoimmune rheumatic diseases involving connective tissue.

\section{Search Method}

We searched for randomized clinical trials conducted on dietary intervention in patients with autoimmune connective tissue diseases, i.e., systemic lupus erythematosus (SLE), idiopathic inflammatory myopathies (IIM), vasculitis, Sjögren's syndrome (SS), and systemic sclerosis (SSc), from inception to 2021. When no RCTs were available for a specific disease, the search was expanded to include clinical non-randomized studies. Databases included Medline, Embase, and the trial registry clinicaltrial.gov. 


\section{Evidence from Randomized Clinical Trials}

\subsection{Systemic Lupus Erythematosus}

\subsubsection{Omega-3 Polyunsaturated Fatty Acids}

Omega (n)-3 polyunsaturated fatty acids are among the most studied of dietary interventions in SLE. The first RCTs conducted on these nutrients date back to the 1990s, when the beneficial clinical immunological and biochemical effect of fish oil was demonstrated in several animal disease models [1,2]. The epidemiological observation of a very low incidence of autoimmune and inflammatory disorders in Eskimo populations compared with matched European individuals, in addition to the association between higher intakes of the n-3 fatty acids (eicosapentaenoic acid, EPA, and docosahexaenoic acid, DHA) and lower risk of developing cardiovascular disease, pushed the research in this direction [3]. Since then, an impressive number of experimental and clinical studies have been conducted [4].

The first two RCTs have been performed in patients with active SLE over a period of six months (Table 1) [5,6]. In both studies, n-3 fatty acids were administered through MaxEPA capsules at $0.2 \mathrm{~g} / \mathrm{kg} /$ die [5] or $20 \mathrm{~g} / \mathrm{die}$ [6] according to a crossover design. While the first study showed a limited and short-lived clinical benefit, the second showed a significant benefit on patients' clinical state. Interestingly, an increase in red blood cell EPA concentration was observed in patients receiving MaxEPA [6].

Table 1. Randomized clinical trials investigating the effect of diet and dietary supplementation in systemic lupus erythematosus.

\begin{tabular}{|c|c|c|c|c|c|c|c|c|c|}
\hline & Reference & Trial Type & $\begin{array}{c}\text { Main } \\
\text { Inclusion } \\
\text { Criteria }\end{array}$ & Cases (N.) & Intervention/Die & Control & $\begin{array}{c}\text { Intervention } \\
\text { Period }\end{array}$ & Outcomes & $\begin{array}{l}\text { Main } \\
\text { Results }\end{array}$ \\
\hline & $\begin{array}{l}\text { Westberg, } \\
1990[5]\end{array}$ & $\begin{array}{l}\text { Randomized, } \\
\text { double blind, } \\
\text { crossover }\end{array}$ & $\begin{array}{l}\text { Active } \\
\text { disease }\end{array}$ & 17 & $\begin{array}{c}\text { MaxEPA } 0.2 \\
\mathrm{~g} / \mathrm{kg}\end{array}$ & Olive oil & 6 months & $\begin{array}{l}\text { Clinical and } \\
\text { laboratory } \\
\text { parameters }\end{array}$ & $\begin{array}{c}\text { Short-lived } \\
\text { benefit }\end{array}$ \\
\hline & $\begin{array}{c}\text { Walton, } 1991 \\
\text { [6] }\end{array}$ & $\begin{array}{l}\text { Randomized, } \\
\text { double blind, } \\
\text { crossover }\end{array}$ & $\begin{array}{l}\text { Active } \\
\text { disease }\end{array}$ & 27 & $\begin{array}{c}\text { Low fat diet } \\
+20 \mathrm{~g} \\
\text { MaxEPA }\end{array}$ & Olive oil & 6 months & $\begin{array}{l}\text { Clinical and } \\
\text { laboratory } \\
\text { parameters }\end{array}$ & $\begin{array}{l}\text { Significant } \\
\text { benefit }\end{array}$ \\
\hline & $\begin{array}{c}\text { Clark, } 1993 \\
\text { [7] }\end{array}$ & $\begin{array}{l}\text { Randomized, } \\
\text { double blind, } \\
\text { placebo } \\
\text { controlled, } \\
\text { crossover }\end{array}$ & $\begin{array}{c}\text { Stable active } \\
\text { disease, with } \\
\text { nephritis }\end{array}$ & 26 & $\begin{array}{c}\text { Fish oil ( } 2.7 \\
\text { g EPA, } 1.7 \mathrm{~g} \\
\text { DHA) }\end{array}$ & Olive oil & 12 months & $\begin{array}{l}\text { Renal } \\
\text { function, } \\
\text { plasma } \\
\text { lipids, } \\
\text { SLEDAI, im- } \\
\text { munological } \\
\text { markers }\end{array}$ & $\begin{array}{l}\text { No changes } \\
\text { in renal } \\
\text { function or } \\
\text { SLEDAI and- } \\
\text { significant } \\
\text { decrease } \\
\text { in TG and } \\
\text { VLDL levels }\end{array}$ \\
\hline & $\begin{array}{c}\text { Clark, } 2001 \\
{[8]}\end{array}$ & $\begin{array}{l}\text { Randomized, } \\
\text { double blind, } \\
\text { non-placebo } \\
\text { controlled, } \\
\text { crossover }\end{array}$ & $\begin{array}{l}\text { Hematuria, } \\
\text { proteinuria }\end{array}$ & $\begin{array}{c}23 \\
(23 c+23 p)\end{array}$ & $\begin{array}{c}\text { Flaxseeds } 30 \\
\mathrm{~g}\end{array}$ & No flaxseeds & 24 months & $\begin{array}{c}\text { Renal } \\
\text { function, } \\
\text { plasma } \\
\text { lipids }\end{array}$ & $\begin{array}{l}\text { Some reno- } \\
\text { protective } \\
\text { effects, poor } \\
\text { adherence }\end{array}$ \\
\hline \multirow[t]{4}{*}{$\begin{array}{l}\text { n-3 fatty } \\
\text { acids }\end{array}$} & $\begin{array}{c}\text { Duffy, } 2004 \\
\text { [9] }\end{array}$ & $\begin{array}{l}\text { Randomized, } \\
\text { double blind, } \\
\text { double } \\
\text { placebo } \\
\text { controlled, } \\
\text { factorial }\end{array}$ & $\begin{array}{l}\text { Stable active } \\
\text { disease }\end{array}$ & $\begin{array}{c}52 \\
(13 c+14 c \\
+13 c+12 p)\end{array}$ & $\begin{array}{l}\text { MaxEPA fish } \\
\text { oil } 3 \mathrm{~g}, \\
\text { copper } 3 \mathrm{mg}\end{array}$ & $\begin{array}{l}\text { Double } \\
\text { placebo } \\
\text { (olive oil) }\end{array}$ & 6 months & $\begin{array}{l}\text { Disease } \\
\text { activity. } \\
\text { Biochemical } \\
\text { and im- } \\
\text { munological } \\
\text { markers }\end{array}$ & $\begin{array}{l}\text { Significant } \\
\text { reduction } \\
\text { in SLAM-R }\end{array}$ \\
\hline & $\begin{array}{c}\text { Wright, } 2008 \\
\text { [10] }\end{array}$ & $\begin{array}{l}\text { Randomized, } \\
\text { double blind, } \\
\text { placebo } \\
\text { controlled, } \\
\text { parallel }\end{array}$ & $\begin{array}{l}\text { SLE without } \\
\text { comorbidi- } \\
\text { ties }\end{array}$ & $\begin{array}{c}60 \\
(30 c+30 p)\end{array}$ & $\begin{array}{c}\text { Fish oil (1.8 } \\
\text { g EPA, } 1.2 \mathrm{~g} \\
\text { DHA) } \\
\text { capsules }\end{array}$ & $\begin{array}{l}\text { Olive oil } \\
\text { capsules }\end{array}$ & 6 months & $\begin{array}{l}\text { Disease } \\
\text { activity, } \\
\text { endothelial } \\
\text { functions }\end{array}$ & $\begin{array}{c}\text { Significant } \\
\text { reduction } \\
\text { in SLAM-R, } \\
\text { BILAG, } \\
\text { and TG and } \\
\text { significant } \\
\text { increase } \\
\text { in FMD and } \\
\text { decrease } \\
\text { in DSS }\end{array}$ \\
\hline & $\begin{array}{l}\text { Arriens, } \\
2015 \text { [11] }\end{array}$ & $\begin{array}{l}\text { Randomized, } \\
\text { single blind, } \\
\text { placebo } \\
\text { controlled }\end{array}$ & $\begin{array}{l}\text { SLE with } \\
\text { ACR criteria }\end{array}$ & $\begin{array}{c}50 \\
(25 c+25 p)\end{array}$ & $\begin{array}{c}\text { Fish oil }(2.25 \\
\text { g EPA, } 2.25 \mathrm{~g} \\
\text { DHA) } \\
\text { capsules }\end{array}$ & $\begin{array}{l}\text { Olive oil } \\
\text { capsules }\end{array}$ & 6 months & $\begin{array}{c}\text { Fatigue, } \\
\text { QoL, disease } \\
\text { activity, in- } \\
\text { flammatory } \\
\text { biomarkers }\end{array}$ & $\begin{array}{c}\text { Improvement } \\
\text { in global } \\
\text { disease } \\
\text { assessment } \\
\text { Non- } \\
\text { significant } \\
\text { improve- } \\
\text { ment } \\
\text { in fatigue } \\
\text { and decrease } \\
\text { in ESR and } \\
\text { IL-12 }\end{array}$ \\
\hline & $\begin{array}{c}\text { Borges, } 2016 \\
{[12]}\end{array}$ & $\begin{array}{c}\text { Randomized, } \\
\text { parallel, } \\
\text { pilot study }\end{array}$ & $\begin{array}{l}\text { Female with } \\
\text { SLE of } \\
\text { disease } \\
\text { duration }>1 \\
\text { year }\end{array}$ & $\begin{array}{c}49 \\
(22 c+27 p)\end{array}$ & $\begin{array}{c}\text { n-3 fatty } \\
\text { acids (540 } \\
\text { mg EPA, } 100 \\
\text { mg DHA), } \\
\text { tablets }\end{array}$ & $\stackrel{\text { No }}{\text { intervention }}$ & 3 months & $\begin{array}{l}\text { Biochemical } \\
\text { inflamma- } \\
\text { tory and } \\
\text { lipid } \\
\text { markers }\end{array}$ & No benefit \\
\hline
\end{tabular}


Table 1. Cont.

\begin{tabular}{|c|c|c|c|c|c|c|c|c|c|}
\hline & Reference & Trial Type & $\begin{array}{c}\text { Main } \\
\text { Inclusion } \\
\text { Criteria }\end{array}$ & Cases (N.) & Intervention/Die & Control & $\begin{array}{l}\text { Intervention } \\
\text { Period }\end{array}$ & Outcomes & $\begin{array}{c}\text { Main } \\
\text { Results }\end{array}$ \\
\hline \multirow{4}{*}{$\begin{array}{l}\text { Nutritional } \\
\text { intervention }\end{array}$} & $\begin{array}{c}\text { Shah, } 2002 \\
\text { [13] }\end{array}$ & $\begin{array}{l}\text { Randomized, } \\
\text { controlled, } \\
\text { double blind }\end{array}$ & $\begin{array}{c}\text { Disease } \\
\text { lasting } 6 \\
\text { months, } \\
\mathrm{LDL} \geq 100 \\
\mathrm{mg} / \mathrm{dL}\end{array}$ & $\begin{array}{c}17 \\
(8 c+7 p)\end{array}$ & $\begin{array}{l}\text { NCEP Step } \\
\text { II diet }\end{array}$ & $\begin{array}{l}\text { No dietary } \\
\text { advice }\end{array}$ & 3 months & QoL, lipids & $\begin{array}{l}\text { Improvement } \\
\text { in QOL and } \\
\text { short benefit } \\
\text { for lipids }\end{array}$ \\
\hline & $\begin{array}{c}\text { Davies, } 2012 \\
{[14]}\end{array}$ & $\begin{array}{l}\text { Randomized, } \\
\text { controlled, } \\
\text { double blind }\end{array}$ & $\begin{array}{l}\text { Mild and } \\
\text { stable } \\
\text { disease } \\
\text { treated with } \\
\text { corticos- } \\
\text { teroids }\end{array}$ & $\begin{array}{c}23 \\
(11 c+12 p)\end{array}$ & $\begin{array}{c}\text { Low } \\
\text { glycemic } \\
\text { index diet }\end{array}$ & $\begin{array}{l}\text { Calorie- } \\
\text { restricted } \\
\text { diet }\end{array}$ & 6 weeks & $\begin{array}{l}\text { Weight loss, } \\
\text { CV risk } \\
\text { markers, } \\
\text { disease } \\
\text { activity, } \\
\text { sleep quality }\end{array}$ & $\begin{array}{l}\text { Significant } \\
\text { weight loss } \\
\text { and } \\
\text { reduction of } \\
\text { fatigue } \\
\text { in both } \\
\text { groups }\end{array}$ \\
\hline & $\begin{array}{l}\text { Da Silva, } \\
2018 \text { [15] }\end{array}$ & $\begin{array}{l}\text { Randomized, } \\
\text { controlled, } \\
\text { single blind }\end{array}$ & $\begin{array}{l}\text { Juvenile SLE } \\
\text { for at least } 6 \\
\text { months }\end{array}$ & $\begin{array}{c}31 \\
(15 c+16 p)\end{array}$ & $\begin{array}{l}\text { Nutritional } \\
\text { instruction }\end{array}$ & $\begin{array}{l}\text { No dietary } \\
\text { advises }\end{array}$ & 9 months & $\begin{array}{l}\text { Carbohydrates } \\
\text { and fat } \\
\text { intake, lipid } \\
\text { and glucose } \\
\text { metabolism } \\
\text { biomarkers }\end{array}$ & $\begin{array}{c}\text { Significant } \\
\text { improve- } \\
\text { ment in lipid } \\
\text { metabolism } \\
\text { and } \\
\text { reduction of } \\
\text { CVR }\end{array}$ \\
\hline & $\begin{array}{l}\text { Aranow, } \\
2015 \text { [16] }\end{array}$ & $\begin{array}{l}\text { Randomized, } \\
\text { double blind, } \\
\text { placebo } \\
\text { controlled }\end{array}$ & $\begin{array}{c}\text { Stable, } \\
\text { inactive } \\
\text { disease with } \\
25(\mathrm{OH}) \mathrm{D}< \\
20 \mathrm{ng} / \mathrm{ml}\end{array}$ & $\begin{array}{c}54 \\
(17 c+18 c+ \\
19 p)\end{array}$ & $\begin{array}{c}\text { Low-dose } \\
\text { VitD3 (2000 } \\
\text { IU) } \\
\text { high-dose } \\
\text { VitD3 (4000 } \\
\text { IU) }\end{array}$ & Placebo & 12 weeks & $\begin{array}{l}\text { IFN } \\
\text { signature } \\
\text { response }\end{array}$ & No benefit \\
\hline \multirow[t]{4}{*}{ Vitamin D } & $\begin{array}{l}\text { Andreoli, } \\
2015 \text { [17] }\end{array}$ & $\begin{array}{l}\text { Randomized, } \\
\text { double blind, } \\
\text { crossover }\end{array}$ & $\begin{array}{l}\text { Stable } \\
\text { disease }\end{array}$ & $\begin{array}{c}34 \\
(18 c+16 c)\end{array}$ & $\begin{array}{c}\text { VitD3 } \\
50,000 \\
\text { IU/month }\end{array}$ & $\begin{array}{l}\text { Cholecalciferol } \\
25,000 \\
\text { IU/month }\end{array}$ & 24 months & $\begin{array}{l}\text { VitD levels, } \\
\text { disease } \\
\text { activity, } \\
\text { bone } \\
\text { metabolism } \\
\text { markers }\end{array}$ & No benefit \\
\hline & $\begin{array}{c}\text { Kamen, } 2015 \\
{[18]}\end{array}$ & $\begin{array}{l}\text { Randomized, } \\
\text { single blind, } \\
\text { controlled, } \\
\text { pilot study }\end{array}$ & $\begin{array}{c}\text { VitD- } \\
\text { deficient } \\
\text { SLE subjects, } \\
\text { inactive } \\
\text { disease }\end{array}$ & $\begin{array}{c}9 \\
(6 c+3 p)\end{array}$ & $\begin{array}{c}\text { VitD3 } \\
5000 \mathrm{IU}\end{array}$ & $\begin{array}{l}\text { VitD3, } 400 \\
\text { IU/day }\end{array}$ & 16 weeks & $\begin{array}{l}\text { Endothelial } \\
\text { function }\end{array}$ & $\begin{array}{l}\text { Non- } \\
\text { significant } \\
\text { increase } \\
\text { in FMD }\end{array}$ \\
\hline & $\underset{[19]}{\operatorname{Lima}, 2016}$ & $\begin{array}{l}\text { Randomized, } \\
\text { double blind, } \\
\text { placebo } \\
\text { controlled }\end{array}$ & $\begin{array}{l}\text { Juvenile- } \\
\text { onset } \\
\text { SLE }\end{array}$ & $\begin{array}{c}40 \\
(20 c+20 p)\end{array}$ & $\begin{array}{l}\text { VitD3, } \\
50,000 \\
\text { IU /week, } \\
\text { tablets }\end{array}$ & $\begin{array}{l}\text { Placebo } \\
\text { tablets }\end{array}$ & 6 months & $\begin{array}{l}\text { Disease } \\
\text { activity, } \\
\text { fatigue }\end{array}$ & $\begin{array}{c}\text { Significant } \\
\text { improve- } \\
\text { ment } \\
\text { in SLEDAI, } \\
\text { ECLAM, } \\
\text { and fatigue }\end{array}$ \\
\hline & $\underset{[20]}{\operatorname{Lima}, 2018}$ & $\begin{array}{l}\text { Randomized, } \\
\text { double blind, } \\
\text { placebo } \\
\text { controlled }\end{array}$ & $\begin{array}{l}\text { Juvenile- } \\
\text { onset } \\
\text { SLE }\end{array}$ & $\begin{array}{c}40 \\
(20 c+20 p)\end{array}$ & $\begin{array}{l}\text { VitD3, } \\
50,000 \\
\text { IU/week, } \\
\text { tablets }\end{array}$ & $\begin{array}{l}\text { Placebo } \\
\text { tablets }\end{array}$ & 6 months & $\begin{array}{l}\text { Bone } \\
\text { microarchi- } \\
\text { tecture } \\
\text { parameters }\end{array}$ & $\begin{array}{c}\text { Significant } \\
\text { improve- } \\
\text { ment } \\
\text { in trabecular } \\
\text { number }\end{array}$ \\
\hline $\begin{array}{c}\text { Other } \\
\text { vitamins }\end{array}$ & $\underset{[21]}{\operatorname{Tam}, 2005}$ & $\begin{array}{l}\text { Randomized, } \\
\text { double blind, } \\
\text { placebo } \\
\text { controlled }\end{array}$ & $\begin{array}{l}\text { Stable } \\
\text { disease }\end{array}$ & $\begin{array}{c}39 \\
(20 c+19 p)\end{array}$ & $\begin{array}{c}\text { Vitamins } \\
(500 \mathrm{mg} \\
\text { VitC, } 800 \mathrm{IU} \\
\text { VitE) }\end{array}$ & Placebo & 3 months & $\begin{array}{l}\text { Markers of } \\
\text { oxidative } \\
\text { stress, } \\
\text { endothelial } \\
\text { function }\end{array}$ & $\begin{array}{l}\text { Modest } \\
\text { reduction } \\
\text { in lipid } \\
\text { peroxidation }\end{array}$ \\
\hline \multirow[t]{2}{*}{ Polyphenols } & $\begin{array}{l}\text { Khajehdehi, } \\
2012 \text { [22] }\end{array}$ & $\begin{array}{c}\text { Randomized, } \\
\text { placebo } \\
\text { controlled }\end{array}$ & $\begin{array}{l}\text { SLE with } \\
\text { relapsing or } \\
\text { refractory } \\
\text { nephritis }\end{array}$ & $\begin{array}{c}24 \\
(12 c+12 p)\end{array}$ & $\begin{array}{l}\text { Turmeric } 500 \\
\text { mg }(22.1 \mathrm{mg} \\
\text { curcumin), } \\
\text { capsules }\end{array}$ & $\begin{array}{l}\text { Starch } \\
\text { capsules }\end{array}$ & 3 months & $\begin{array}{c}\text { Renal } \\
\text { functions, } \\
\text { hematologi- } \\
\text { cal } \\
\text { parameters }\end{array}$ & $\begin{array}{c}\text { Significant } \\
\text { decrease } \\
\text { in protein- } \\
\text { uria, } \\
\text { hematuria } \\
\text { and systolic } \\
\text { blood } \\
\text { pressure }\end{array}$ \\
\hline & $\begin{array}{l}\text { Shamekh, } \\
2017 \text { [23] }\end{array}$ & $\begin{array}{l}\text { Randomized, } \\
\text { double blind, } \\
\text { placebo } \\
\text { controlled }\end{array}$ & $\begin{array}{l}\text { Stable } \\
\text { disease }\end{array}$ & $\begin{array}{c}31 \\
(32 c+66 p)\end{array}$ & $\begin{array}{l}\text { Green tea } \\
\text { extract, } 1000 \\
\text { mg, capsules }\end{array}$ & $\begin{array}{c}\text { Starch, } 1000 \\
\text { mg/day, } \\
\text { capsules }\end{array}$ & 3 months & $\begin{array}{c}\text { Disease } \\
\text { activity, QoL }\end{array}$ & $\begin{array}{c}\text { Significant } \\
\text { improve- } \\
\text { ment } \\
\text { in SLEDAI } \\
\text { Benefit on } \\
\text { QoL }\end{array}$ \\
\hline Creatine & $\begin{array}{l}\text { Hayashi, } \\
2014[24]\end{array}$ & $\begin{array}{l}\text { Randomized, } \\
\text { double blind, } \\
\text { placebo } \\
\text { controlled, } \\
\text { crossover }\end{array}$ & $\begin{array}{l}\text { Childhood- } \\
\text { onset SLE } \\
\text { with } \\
\text { SLEDAI-2K } \\
<8\end{array}$ & $\begin{array}{c}15 \\
(7 c+8 p)\end{array}$ & $\begin{array}{l}\text { Creatine } \\
\text { monohy- } \\
\text { drate } 0.1 \\
\mathrm{~g} / \mathrm{kg} \text {, juice }\end{array}$ & $\begin{array}{l}\text { Dextrose, } \\
\text { juice }\end{array}$ & $\begin{array}{c}12 \text { weeks }+8 \\
\text { washout }\end{array}$ & $\begin{array}{c}\text { Muscle } \\
\text { function } \\
\text { Biochemical } \\
\text { markers, } \\
\text { QoL }\end{array}$ & No benefit \\
\hline
\end{tabular}

ACR: American College of Rheumatology; BILAG: British Isles Lupus Assessment Group; CVR: cardiovascular risk; DHA: docosahexaenoic acid; DSS: diastolic shear stress during reactive hyperemia; ECLAM: European Consensus Lupus Activity Measurement; EPA: eicosapentaenoic acid; ESR: erythrocyte sedimentation rate; FMD: flow-mediated dilation of the brachial artery; LDL: low-density lipoprotein; NCEP:

National Cholesterol Education Program; QoL: quality of life; SLAM-R: Systemic Lupus Activity Measure, revised; SLEDAI: Systemic Lupus Erythematosus Disease Activity Index; TG: triglycerides; VLDL: very low-density lipoprotein.

Another crossover trial conducted in patients with SLE and nephritis [7] aimed at investigating the effect of EPA and DHA in renal function. No significant changes in clinical scores and renal function measures were observed in this study, including for proteinuria, glomerular filtration rate, urinary $\operatorname{IgG}$, and serum creatine. However, supplementation with fish oil caused a reduction in values for a few lipid parameters, such as triglycerides and 
VLDL levels. Despite the crossover design, a small sample size and the lack of validated measures of disease activity characterized and represent limitations of the mentioned studies. Furthermore, the choice of olive oil as a control has been supposed to represent a potential source of error due to its possible underestimated active effect [7].

Flaxseeds have been used in patients with documented hematuria and proteinuria to evaluate the effect of alpha-linolenic acid, the precursor of $n-3$ fatty acids, in renal function [8]. A two-year crossover non-placebo-controlled trial demonstrated that $30 \mathrm{~g}$ of flaxseeds administered daily induced a renoprotective effect in lupus but were difficult to tolerate in the long term, leading to poor adherence to the intervention and thus affecting the results of the study.

A larger cohort of patients has been included in another study evaluating the effect of $3 \mathrm{~g} /$ die of MaxEPA and $3 \mathrm{mg}$ copper in patients with active disease [9]. This six-month trial that had a double placebo design showed a significant reduction in disease activity assessed by the SLAM-R (Systemic Lupus Activity Measure, revised) scoring system but no significant therapeutic benefit from copper supplementation. Contrary to the previous studies, this trial used a validated index for determining lupus activity considering different clinical and laboratory domains and is the first showing a potential beneficial role of $n-3$ fatty acids in SLE [9].

With the introduction of validated disease activity scores, other interventional trials on $\mathrm{n}-3$ supplementation have been concluded. The benefit on disease activity has been confirmed in a placebo-controlled RCT conducted in 60 patients [10]. After a period of six months of fish oil administration, the patients showed a significant reduction in SLAM-R and BILAG indices and, importantly, an improvement in endothelial function as measured by vascular indices including flow-mediated dilation of the brachial artery and diastolic shear stress.

Using different concentrations of n-3 EPA and DHA, other authors did not find any significant benefit on disease activity and fatigue in a population of 50 patients with SLE [11]. However, they developed an improved version of the physician global disease assessment. Regarding inflammatory circulating markers, the supplementation with n-3 fatty acids showed no impact on serum concentrations of the cytokines IL-6 and IL-10, and adipokines leptin and adiponectin [12], whereas it exhibited a small effect on IL-13 [11].

\subsubsection{Nutritional Counseling}

Considering the higher prevalence of atherosclerotic cardiovascular disease in patients with SLE [25], some RCTs have been designed to examine the effect of nutritional intervention in patients' lipid profiles [13-15].

The first of these studies applied dietary counseling based on the National Cholesterol Education Program (NCEPT) on patients with SLE to investigate lipid and lipoprotein levels [13]. Although highly accepted and effective in changing nutrient intakes and in improving the quality of life, the diet program induced only a modest effect on serum lipid, lipoprotein, and body weight after three months [13].

\subsubsection{Low Carbohydrate Diet}

Based on a similar concept, a low carbohydrate diet was assigned to a small cohort of patients with SLE to minimize the adverse effects of corticosteroids on glycemic control. This six-week study demonstrated the effectiveness of this diet in reducing weight comparably to a standard low-calorie diet, with both being safe and well-tolerated by the patients [14]. Notably, the patients showed a significant improvement in terms of the fatigue severity scale, suggesting an important role of diet in managing fatigue in SLE.

A population of adolescents with juvenile SLE were included in an RCT evaluating the effect of a nutritional intervention on cardiovascular risk-related lipid metabolism biomarkers and their variation over a period of nine months [15]. Compared with a control group that did not receive any dietary instruction, the nutritional intervention group of 
adolescents showed a reduced carbohydrate, total fat, and calorie intake, with a significant improvement in their lipid marker profile.

\subsubsection{Vitamin D and Other Vitamins}

Another important nutrient with recognized immunomodulatory effects is vitamin D (VitD). Considered a booster of the immune system, VitD has been used in various RCT demonstrating contrasting results (Table 1). Different doses of VitD for periods of treatment ranging from three to six months were assessed in these studies. The daily supplementation of 2000 and 4000 IU showed no benefit on IFN signature response, evaluated through the analysis of IFN $\alpha$-inducible genes, nor according to SELENA-SLEDAI disease activity index in clinically stable VitD-deficient patients with SLE [16]. Similarly, a crossover study on stable patients taking a monthly dosage of VitD according to an intensive (300,000 IU at baseline $+50,000 \mathrm{IU} /$ month) and a standard (25,000 IU/month) regimen, showed no significant influence on SLEDAI disease activity index nor in complement levels and bone metabolism markers [17]. VitD-deficient patients with inactive SLE were also enrolled in a pilot study investigating the effect of $5000 \mathrm{IU} /$ daily on endothelial function. Although the study was limited by a very small cohort of patients, no increase in flow-mediated dilation of the brachial artery was observed [18].

By contrast, two more recent placebo-controlled RCT carried out on juvenile-onset patients demonstrated that weekly administration of 50,000 IU VitD led to a significant improvement in SLEDAI and ECLAM indices along with reduced fatigue [19]. When looking at microarchitecture parameters, the treated adolescents showed a higher increase in the trabecular number at the tibia site compared to the placebo group after six months of VitD treatment. No difference was observed in volumetric bone mineral density in the two groups after supplementation [20]. The explanation for the different results achieved by the studies might lie in the different target populations, the inactive disease of some patients, the different doses and period treatment, and the difficulty to maintain sufficient VitD serum levels [17]. Given the safety of this nutrient, it will be important to identify those patients more likely to benefit from VitD supplementation.

Among other vitamins, vitamins $C$ and $E$ have been tested in patients with stable SLE disease to verify their antioxidant effects on oxidative stress markers and endothelial function, but only a modest reduction in lipid peroxidation was found after three months of therapy (Table 1) [21].

\subsubsection{Plant Polyphenols}

In the last few decades, great interest has been devoted to the anti-inflammatory and immunomodulatory properties of plant polyphenols. Their beneficial effects have been tested and demonstrated for several inflammatory, autoimmune, and degenerative diseases [26-29].

Regarding SLE, two different RCTs considered a three-month polyphenol supplementation. Restored renal function was the outcome of the first of these studies and was carried out in patients with relapsing or refractory nephritis taking $22 \mathrm{~g} /$ day curcumin. Compared to a control group taking a placebo, the treated group showed a significant decrease in proteinuria and hypertension, which represents an adverse prognostic sign in patients with lupus nephritis [22]. A second trial demonstrated that $1000 \mathrm{mg} / \mathrm{day}$ of green tea extract for three months lead to a significant improvement in the SLEDAI index and a benefit in quality of life in patients with stable disease compared to a placebo group consuming starch capsules as placebo [23].

Finally, a three-month study was designed to demonstrate the efficacy and safety of creatine in non-active childhood-onset SLE. The aim was to counteract adverse events associated with the treatment as well as the disease itself. A dose of $0.1 \mathrm{~g} / \mathrm{kg} /$ die creatine supplementation did not show any influence on intramuscular phosphoryl creatine, muscle function, free fat mass, or quality of life [24]. 


\subsection{Idiopathic Inflammatory Myopathies}

Contrary to SLE, only a few RCT studies have examined the role of dietary intervention on the outcome of other connective tissue diseases.

Indeed, idiopathic inflammatory myopathies (IIM), which are characterized, among other features, by systemic and muscle inflammation with an increase in cytokine levels, might benefit from an anti-inflammatory diet or supplementation. Some clinical studies demonstrated, for instance, that vitamin E reduces levels of cell damage markers and the concentration of exercise-induced cytokines in hypoxia, suggesting a possible protective effect against hypoxia-induced inflammation [30]. Polyphenols were demonstrated to protect muscle inflammation and atrophy in a mouse model of chronic inflammation [31], while n-3 fatty acids were shown to prevent lipotoxicity and inflammation through the regulation of muscle lipid and glucose metabolism [32]. An association between dermatomyositis (DM) and celiac disease was documented in children [33] and adults [34], where a strict gluten-free diet can lead to disease resolution [34].

With respect to dietary interventional trials, three RCTs have been carried out in idiopathic inflammatory myopathies and are shown in Table 2. The first is the largest as it involved patients with both polymyositis (PM) and dermatomyositis (DM) that were assigned to receive a loading followed by a maintenance dose of creatine in combination with home exercise [35]. Compared to the placebo group (exercise alone), patients has improved muscle performance assessed as by a composite measure (Table 2) and endurance work after six months of treatment. The choice of creatine in IIM found its rationale in the reduced levels of intramuscular phosphocreatine in patients with IIM and increased creatine excretion, which was shown to be correlated with global disease damage in juvenile DM [36].

Table 2. Randomized clinical trials on the effect of diet in idiopathic inflammatory myopathies.

\begin{tabular}{|c|c|c|c|c|c|c|c|c|}
\hline Reference & Study Type & $\begin{array}{c}\text { Main } \\
\text { Inclusion } \\
\text { Criteria }\end{array}$ & Cases (N.) & Intervention & Control & $\begin{array}{l}\text { Intervention } \\
\text { Period }\end{array}$ & Outcomes & $\begin{array}{l}\text { Main } \\
\text { Results }\end{array}$ \\
\hline $\begin{array}{c}\text { Chung, } 2007 \\
{[35]}\end{array}$ & $\begin{array}{l}\text { Randomized, } \\
\text { double blind, } \\
\text { placebo } \\
\text { controlled }\end{array}$ & PM or DM & $\begin{array}{c}37 \\
(19 c+18 p)\end{array}$ & $\begin{array}{l}\text { Creatine, } 20 \\
\text { g/day for } 8 \\
\text { days, } 3 \\
\text { g/day plus } \\
\text { exercise }\end{array}$ & $\begin{array}{l}\text { Placebo plus } \\
\text { exercise }\end{array}$ & 6 months & $\begin{array}{l}\text { Aggregate } \\
\text { functional } \\
\text { performance } \\
\text { time, } \\
\text { functional } \\
\text { index }\end{array}$ & $\begin{array}{c}\text { Significant } \\
\text { improve- } \\
\text { ment } \\
\text { in muscle } \\
\text { performance } \\
\text { and } \\
\text { functional } \\
\text { index }\end{array}$ \\
\hline $\begin{array}{c}\text { Solis, } 2015 \\
\text { [37] }\end{array}$ & $\begin{array}{l}\text { Randomized, } \\
\text { double blind, } \\
\text { placebo } \\
\text { controlled, } \\
\text { crossover }\end{array}$ & $\begin{array}{l}\text { Juvenile DM } \\
\text { with stable } \\
\text { medications }\end{array}$ & 15 & $\begin{array}{l}\text { Creatine } \\
\text { monohy- } \\
\text { drate, } 0.1 \\
\text { g/kg/die }\end{array}$ & Dextrose & 3 months & $\begin{array}{l}\text { Muscle } \\
\text { function, } \\
\text { bone } \\
\text { remodeling, } \\
\text { and inflam- } \\
\text { matory } \\
\text { markers }\end{array}$ & $\begin{array}{l}\text { No effect on } \\
\text { muscle } \\
\text { function }\end{array}$ \\
\hline $\begin{array}{c}\text { Dover, } 2021 \\
{[38]}\end{array}$ & $\begin{array}{l}\text { Randomized, } \\
\text { double blind, } \\
\text { placebo } \\
\text { controlled, } \\
\text { multiple } \\
\text { baseline } \\
\text { design }\end{array}$ & $\begin{array}{l}\text { Juvenile DM } \\
\text { with stable } \\
\text { medications }\end{array}$ & 13 & $\begin{array}{c}\text { Creatine, } 150 \\
\mathrm{mg} / \mathrm{kg} / \text { die, } \\
\text { tablets }\end{array}$ & $\begin{array}{l}\text { Placebo } \\
\text { tablets }\end{array}$ & 6 months & $\begin{array}{c}\text { Muscle } \\
\text { function and } \\
\text { metabolism, } \\
\text { fatigue, QoL }\end{array}$ & $\begin{array}{l}\text { No clinical } \\
\text { benefit, } \\
\text { significant } \\
\text { improve- } \\
\text { ment } \\
\text { in muscle } \\
\text { metabolism }\end{array}$ \\
\hline
\end{tabular}

DM: dermatomyositis; PM: polymyositis.

Based on these findings, other two RCTs involving pediatric cohorts were designed to investigate the role of creatine in physical capacity and quality of life. Both studies included patients with juvenile DM that received creatine for either three or six months, but they failed to demonstrate significant clinical benefit [37,38].

\subsection{Vasculitis}

Only a proof-of-concept clinical study has addressed the possible influence of diet in vasculitis and concerns Behçet's disease. In this disease, the depletion of some strains of 
microorganisms in the gut microbiota is observed. Therefore, the decreased production of anti-inflammatory short-chain fatty acids (SCFA) was demonstrated [39]. These metabolites, including butyrate, acetate, and propionate, have been shown to possess positive immune-modulating activity by modifying the cytokine production profile of $\mathrm{T}$ helper cells, promoting intestinal epithelial barrier integrity, resolving intestinal inflammation, and regulating the acetylation of lysine residues, a covalent modification that affects proteins involved in a variety of signaling and metabolic processes [40].

As reported in Table 3, the effects of two butyrate-rich diets on blood redox status, fibrin degradation, and clinical modifications were assessed in patients with Behçet disease. After an intervention period of three months, both diets lead to a significant reduction in leukocyte ROS production and plasma lipid peroxidation and an increase in plasma total antioxidant capacity. Although disease activity significantly improved, the results were not associated with modified SCFA production, which presumably occurs after longer periods of nutritional intervention [41,42].

Table 3. Randomized clinical trials on dietary intervention in Behçet's disease.

\begin{tabular}{|c|c|c|c|c|c|c|c|c|}
\hline Reference & Study Type & $\begin{array}{c}\text { Main } \\
\text { Inclusion } \\
\text { Criteria }\end{array}$ & Cases (N.) & Intervention & Control & $\begin{array}{l}\text { Intervention } \\
\text { Period }\end{array}$ & Outcomes & Main Results \\
\hline $\begin{array}{c}\text { Pagliai, } 2020 \\
\text { [41] }\end{array}$ & $\begin{array}{l}\text { Randomized, } \\
\text { open, } \\
\text { crossover }\end{array}$ & $\begin{array}{l}\text { BD without } \\
\text { any other } \\
\text { autoimmune } \\
\text { disease }\end{array}$ & 90 & $\begin{array}{l}\text { Lacto-ovo- vegetarian } \\
\text { diet } \\
\text { Mediterranean diet } \\
\text { Mediterranean diet + } \\
\text { butyrate }\end{array}$ & - & 3 months & $\begin{array}{l}\text { Gastrointestinal } \\
\text { and systemic } \\
\text { symptoms }\end{array}$ & $\begin{array}{l}\text { Study } \\
\text { protocol }\end{array}$ \\
\hline$\underset{[42]}{E m m i,} 2021$ & $\begin{array}{l}\text { Randomized, } \\
\text { open, parallel }\end{array}$ & $\begin{array}{c}\text { BD on stable } \\
\text { treatment }\end{array}$ & $\begin{array}{c}17 \\
(8 c+9 p)\end{array}$ & $\begin{array}{l}\text { Butyrate }(2.4 \mathrm{~g} / \text { day }) \\
\text { Lacto-ovo-vegetarian } \\
\text { diet leading to } \\
\text { increased butyrate } \\
\text { production }\end{array}$ & - & 3 months & $\begin{array}{l}\text { Blood redox } \\
\text { status, fibrin } \\
\text { degradation, } \\
\text { and clinical } \\
\text { modifications }\end{array}$ & $\begin{array}{l}\text { Significant } \\
\text { improvement } \\
\text { in redox } \\
\text { status and } \\
\text { reduction } \\
\text { in disease } \\
\text { activity }\end{array}$ \\
\hline
\end{tabular}

BD: Behçet's disease.

\subsection{Sjögren's Syndrome}

As a complex autoimmune condition with a wide range of disruptive symptoms, SS might benefit from a diet rich in immunomodulatory substances, including polyunsaturated fatty acids and bioactive compounds. An association between adherence to the Mediterranean diet and a lower likelihood of having primary SS has been observed [43]. In support of the role of nutrition in SS, it has been shown that a lifelong gluten-free diet reduced the infiltration of monocytes/macrophages and $\mathrm{T}$ cells in salivary glands in diabetic mice developing sialadenitis [44]. Although still partial, this evidence sustains the multifaceted relation between immunopathological features of different autoimmune diseases and the capacity of specific dietary compounds in modulating disease onset as well as expression in SS.

As shown in Table 4, randomized clinical trials are still scarce in SS. The deficiency of vitamin B6 in patients with SS and its association with altered T helper cells and IL-2 production has prompted some researchers to investigate the role of pyridoxine in IL-2 release from cultured T lymphocytes collected from SS and healthy subjects randomized to receive the vitamin or the placebo. Although no effect was evidenced at the end of the three-month study, the authors did not exclude the influence of pyridoxine at a different molecular level [45]. 
Table 4. Randomized clinical trials on dietary intervention in Sjögren's syndrome.

\begin{tabular}{|c|c|c|c|c|c|c|c|c|}
\hline Reference & Study Type & $\begin{array}{c}\text { Main } \\
\text { Inclusion } \\
\text { Criteria }\end{array}$ & Cases (N.) & $\begin{array}{c}\text { Intervention/ } \\
\text { Daily }\end{array}$ & Control & $\begin{array}{l}\text { Intervention } \\
\text { Period }\end{array}$ & Outcomes & Main Results \\
\hline $\begin{array}{c}\text { Tovar, } 2002 \\
{[45]}\end{array}$ & $\begin{array}{l}\text { Randomized, } \\
\text { double blind, } \\
\text { placebo } \\
\text { controlled, } \\
\text { crossover }\end{array}$ & Primary SS & $\begin{array}{l}20 c+14 \\
\text { healthysub- } \\
\text { jects }\end{array}$ & $\begin{array}{l}\text { Pyridoxine } 25 \\
\text { mg }\end{array}$ & Placebo & 3 months & $\begin{array}{l}\text { IL-2 } \\
\text { production } \\
\text { in cultured } \\
\text { lymphocytes }\end{array}$ & $\begin{array}{l}\text { No difference } \\
\text { between } \\
\text { patients and } \\
\text { healthy } \\
\text { controls }\end{array}$ \\
\hline $\begin{array}{c}\text { Singh, } 2010 \\
{[46]}\end{array}$ & $\begin{array}{l}\text { Randomized, } \\
\text { double } \\
\text { masked, } \\
\text { placebo } \\
\text { controlled }\end{array}$ & $\begin{array}{l}\text { Primary or } \\
\text { secondary SS }\end{array}$ & $\begin{array}{c}61 \\
(38 c+23 c)\end{array}$ & $\begin{array}{c}\text { n-3 fatty acids } \\
\text { (450 mg EPA, } \\
300 \text { mg DHA) } \\
+ \text { VitE }\end{array}$ & $\begin{array}{l}\text { Wheat germ } \\
\text { oil }\end{array}$ & 3 months & $\begin{array}{c}\text { Saliva } \\
\text { secretion, } \\
\text { inflammatory } \\
\text { markers }\end{array}$ & $\begin{array}{l}\text { Increased } \\
\text { salivary } \\
\text { production } \\
\text { with no } \\
\text { difference } \\
\text { between } \\
\text { groups }\end{array}$ \\
\hline
\end{tabular}

Another RCT investigated the role of n-3 fatty acids in improving SS symptoms, especially dry mouth and salivary secretion. Conducted in 61 patients over a threemonth period, the study showed that $\mathrm{n}-3$ supplementation may improve salivary secretion, but the effect was similar to that obtained with wheat germ oil also containing a certain amount of the n-3 precursor linolenic acid [46].

\subsection{Systemic Sclerosis (SSc)}

Very few studies have been conducted on the effect of dietary supplementation in SSc. Most of these were performed on the comorbidities related to this autoimmune condition. Gastrointestinal symptoms are a frequent comorbidity in SSc and represent one of the most important risk factors for malnutrition in the disease. It was shown that the combined assessment of nutritional parameters, including pre-albumin and disease activity, improves the evaluation of mortality risk in SSc [47]. Consequently, nutritional assessment and, more importantly, dietary intervention should be pursued in these patients.

Recently, SSc was found to be associated with altered intestinal microbiota, but the relationship between dysbiosis and the pathogenesis and features of the disease are not completely clear [48]. Starting from the above observations, probiotics have been tested for their known modulatory action on microbiota and immune system in patients with SSc and gastrointestinal involvement (Table 5). An 8-week RCT showed that probiotic supplementation did not have any effect in reducing gastrointestinal symptoms but led to a decrease in Th17 cell levels, indicating an immunomodulatory capacity of the probiotic strains used in the study [49]. Significant findings have been evidenced in another trial, where the efficacy of probiotics in systemic sclerosis-associated gastrointestinal disease was positively evaluated regarding gastrointestinal reflux. The SSc clinical outcomes were not, however, evaluated in that study [50].

A more dated study addressed the effect of fish oil supplementation on Raynaud's phenomenon secondary to SSc [51]. While the ingestion of fish oil improved tolerance to cold exposure and delayed the onset of vasospasm in patients with the primary disorder, it showed no effect on Raynaud's phenomenon secondary to SSc. 
Table 5. Randomized clinical trials on dietary intervention in systemic sclerosis.

\begin{tabular}{|c|c|c|c|c|c|c|c|c|}
\hline Reference & Study Type & $\begin{array}{c}\text { Main } \\
\text { Inclusion } \\
\text { Criteria }\end{array}$ & Cases (N.) & $\begin{array}{c}\text { Intervention/ } \\
\text { Daily }\end{array}$ & Control & $\begin{array}{l}\text { Intervention } \\
\text { Period }\end{array}$ & Outcomes & Main Results \\
\hline $\begin{array}{c}\text { Marighela, } \\
2019 \text { [49] }\end{array}$ & $\begin{array}{l}\text { Randomized, } \\
\text { double blind, } \\
\text { placebo } \\
\text { controlled }\end{array}$ & $\begin{array}{c}\text { Moderate- } \\
\text { severe SSc } \\
\text { with GI } \\
\text { involvement }\end{array}$ & $\begin{array}{c}73 \\
(37 c+36 p)\end{array}$ & $\begin{array}{c}\text { Probiotics } \\
\text { (L. paracasei, } L \text {. } \\
\text { rhamnosus, L. } \\
\text { acidophillus, } \\
\text { B. lactis) } 10^{9} \\
\text { CFU / each }\end{array}$ & Placebo & 2 months & $\begin{array}{l}\text { GI symptoms, } \\
\text { Th levels }\end{array}$ & $\begin{array}{l}\text { No benefit on } \\
\text { GI symptoms, } \\
\text { reduction } \\
\text { in Th17 cell } \\
\text { levels }\end{array}$ \\
\hline Low, 2019 [50] & $\begin{array}{l}\text { Randomized, } \\
\text { double blind, } \\
\text { placebo } \\
\text { controlled } \\
\text { parallel group }\end{array}$ & $\begin{array}{l}\text { Primary or } \\
\text { secondary SS }\end{array}$ & $\begin{array}{c}40 \\
(19 c+21 p)\end{array}$ & $\begin{array}{c}\text { Probiotics } \\
(\text { multistrain } \\
\text { supplement }^{*} \text { ) } \\
1800 \text { billion } \\
\text { CFU }\end{array}$ & Placebo & 2 months & $\begin{array}{l}\text { GI symptoms, } \\
\text { HAQ-DI }\end{array}$ & $\begin{array}{l}\text { Improvement } \\
\text { in GI reflux }\end{array}$ \\
\hline $\begin{array}{c}\text { DiGiacomo, } \\
1989 \text { [51] }\end{array}$ & $\begin{array}{l}\text { Randomized, } \\
\text { double blind, } \\
\text { placebo } \\
\text { controlled }\end{array}$ & $\begin{array}{l}\text { Primary or } \\
\text { secondary } \\
\text { Raynaud's } \\
\text { phenomenon }\end{array}$ & $\begin{array}{c}32 \\
(16 c+16 p)\end{array}$ & $\begin{array}{c}\text { Fish oil } \\
\text { 3.96 g EPA, } \\
2.64 \mathrm{~g} \text { DHA }\end{array}$ & Olive oil & 4 months & $\begin{array}{c}\text { Onset of } \\
\text { vasospasm, } \\
\text { digital } \\
\text { systolic } \\
\text { pressure, } \\
\text { and arterial } \\
\text { flow }\end{array}$ & $\begin{array}{l}\text { Improvement } \\
\text { in primary } \\
\text { but not } \\
\text { secondary } \\
\text { Raynaud }\end{array}$ \\
\hline
\end{tabular}

CFU: colony-forming units; GI: gastrointestinal; HAQ-DI: Health Assessment Questionnaire Disability Index; Th: T helper. ${ }^{*}$ L. paracasei DSM 24;733; L. plantarum DSM 24;730; L. acidophilus DSM 24;735; and L. delbrueckii subsp. bulgaricus DSM 24;734); B. longum DSM 24;736; B. breve DSM 24;732; and B. infantis DSM 24;737; S. thermophilus DSM 24;731.

\section{Discussion}

Connective tissue diseases encompass different complex disorders with an autoimmune background and a broad variety of clinical manifestations. Besides the involvement of connective tissue, these diseases share features, such as fatigue, and comorbidities mainly affecting the cardiovascular system.

Although anti-inflammatory dietary habits have long been recognized to influence these comorbidities, it is not clear how much diet or dietary supplementation might affect the clinical course of patients with connective tissue diseases.

As outlined in this review, most of the RCTs were conducted in SLE and often show varying results. Certainly, some benefit on disease activity indices were obtained using n-3 fatty acids and VitD, even if the different dosages and intervention period make it difficult to compare the various studies [9-11].

Fatigue, which is a common feature in connective tissue disorders, seems to be affected by healthy nutritional intervention and VitD $[14,20]$. Creatine supplementation showed some benefit on muscle performance and metabolism in IIM [35,38] while interesting results for Behçet disease were achieved with a butyrate-enriched diet [42].

Promising data regarding both renal function and disease activity in SLE were obtained for the use of polyphenols. Although the evidence is still limited, the wide range of favorable effects of these compounds already been demonstrated in many chronic diseases support their use as adjuvant therapy in SLE patients.

Finally, although most dietary supplements do not require a medical prescription and supervision, it is always recommended that a doctor be consulted for specific nutritional indications and contraindications.

\section{Conclusions}

The results from RCTs conducted on connective tissue diseases are still too limited to draw firm conclusions on the clinical benefit of dietary intervention under these conditions. Notwithstanding, the results are encouraging and deserve to be explored upon in depth and with larger cohorts of patients.

Author Contributions: F.O. and A.D. conceived and wrote the manuscript; P.G., E.Z., M.G., and P.S contributed to writing and editing the manuscript. All authors have read and agreed to the published version of the manuscript.

Funding: This research received no external funding. 
Institutional Review Board Statement: Not applicable.

Informed Consent Statement: Not applicable.

Data Availability Statement: Not applicable.

Conflicts of Interest: The authors declare no conflict of interest.

\section{References}

1. Prickett, J.D.; Robinson, D.R.; Steinberg, A.D. Effects of dietary enrichment with eicosapentaenoic acid upon autoimmune nephritis in female NZB X NZW/F1 mice. Arthritis Rheum. 1983, 26, 133-139. [CrossRef] [PubMed]

2. Robinson, D.R.; Xu, L.L.; Tateno, S.; Guo, M.; Colvin, R.B. Suppression of autoimmune disease by dietary n-3 fatty acids. J. Lipid Res. 1993, 34, 1435-1444. [CrossRef]

3. Kromann, N.; Green, A. Epidemiological studies in the Upernavik district, Greenland. Incidence of some chronic diseases 1950-1974. Acta Med. Scand. 1980, 208, 401-406. [CrossRef]

4. Innes, J.K.; Calder, P.C. Marine Omega-3 (N-3) Fatty Acids for Cardiovascular Health: An Update for 2020. Int. J. Mol. Sci. 2020, 21, 1362. [CrossRef] [PubMed]

5. Westberg, G.; Tarkowski, A. Effect of MaxEPA in patients with SLE. A double-blind, crossover study. Scand. J. Rheumatol. 1990, 19, 137-143. [CrossRef] [PubMed]

6. Walton, A.J.; Snaith, M.L.; Locniskar, M.; Cumberland, A.G.; Morrow, W.J.; Isenberg, D.A. Dietary fish oil and the severity of symptoms in patients with systemic lupus erythematosus. Ann. Rheum. Dis. 1991, 50, 463-466. [CrossRef] [PubMed]

7. Clark, W.F.; Parbtani, A.; Naylor, C.D.; Levinton, C.M.; Muirhead, N.; Spanner, E.; Huff, M.W.; Philbrick, D.J.; Holub, B.J. Fish oil in lupus nephritis: Clinical findings and methodological implications. Kidney Int. 1993, 44, 75-86. [CrossRef]

8. Clark, W.F.; Kortas, C.; Heidenheim, A.P.; Garland, J.; Spanner, E.; Parbtani, A. Flaxseed in lupus nephritis: A two-year nonplacebo-controlled crossover study. J. Am. Coll. Nutr. 2001, 20 (Suppl. S2), 143-1488. [CrossRef]

9. Duffy, E.M.; Meenagh, G.K.; McMillan, S.A.; Strain, J.J.; Hannigan, B.M.; Bell, A.L. The clinical effect of dietary supplementation with omega-3 fish oils and/or copper in systemic lupus erythematosus. J. Rheumatol. 2004, 31, 1551-1556. [PubMed]

10. Wright, S.A.; O’Prey, F.M.; McHenry, M.T.; Leahey, W.J.; Devine, A.B.; Duffy, E.M.; Johnston, D.G.; Finch, M.B.; Bell, A.L.; McVeigh, G.E. A randomised interventional trial of omega-3-polyunsaturated fatty acids on endothelial function and disease activity in systemic lupus erythematosus. Ann. Rheum. Dis. 2008, 67, 841-848. [CrossRef] [PubMed]

11. Arriens, C.; Hynan, L.S.; Lerman, R.H.; Karp, D.R.; Mohan, C. Placebo-controlled randomized clinical trial of fish oil's impact on fatigue, quality of life, and disease activity in Systemic Lupus Erythematosus. Nutr. J. 2015, 14, 82. [CrossRef] [PubMed]

12. Curado Borges, M.; de Miranda Moura Dos Santos, F.; Weiss Telles, R.; Melo de Andrade, M.V.; Toulson Davisson Correia, M.I.; Lanna, C.C.D. Omega-3 fatty acids, inflammatory status and biochemical markers of patients with systemic lupus erythematosus: A pilot study. Rev. Bras. Reumatol. Engl. Ed. 2017, 57, 526-534. [CrossRef]

13. Shah, M.; Kavanaugh, A.; Coyle, Y.; Adams-Huet, B.; Lipsky, P.E. Effect of a culturally sensitive cholesterol lowering diet program on lipid and lipoproteins, body weight, nutrient intakes, and quality of life in patients with systemic lupus erythematosus. $J$. Rheumatol. 2002, 29, 2122-2128. [PubMed]

14. Davies, R.J.; Lomer, M.C.; Yeo, S.I.; Avloniti, K.; Sangle, S.R.; D'Cruz, D.P. Weight loss and improvements in fatigue in systemic lupus erythematosus: A controlled trial of a low glycaemic index diet versus a calorie restricted diet in patients treated with corticosteroids. Lupus 2012, 21, 649-655. [CrossRef] [PubMed]

15. Da Silva, S.; Terreri, M.T.; Abad, T.; Machado, D.; Fonseca, F.; Hix, S.; Suano-Souza, F.I.; Sarni, R.; Len, C.A. The effect of nutritional intervention on the lipid profile and dietary intake of adolescents with juvenile systemic lupus erythematosus: A randomized, controlled trial. Lupus 2018, 27, 820-827. [CrossRef] [PubMed]

16. Aranow, C.; Kamen, D.L.; Dall'Era, M.; Massarotti, E.M.; Mackay, M.C.; Koumpouras, F.; Coca, A.; Chatham, W.W.; Clowse, M.E.; Criscione-Schreiber, L.G.; et al. Randomized; Double-Blind; Placebo-Controlled Trial of the Effect of Vitamin D3 on the Interferon Signature in Patients With Systemic Lupus Erythematosus. Arthritis Rheumatol. 2015, 67, 1848-1857. [CrossRef]

17. Andreoli, L.; Dall'Ara, F.; Piantoni, S.; Zanola, A.; Piva, N.; Cutolo, M.; Tincani, A. A 24-month prospective study on the efficacy and safety of two different monthly regimens of vitamin D supplementation in pre-menopausal women with systemic lupus erythematosus. Lupus 2015, 24, 499-506. [CrossRef]

18. Kamen, D.L.; Oates, J.C. A Pilot Study to Determine if Vitamin D Repletion Improves Endothelial Function in Lupus Patients. Am. J. Med. Sci. 2015, 350, 302-307. [CrossRef] [PubMed]

19. Lima, G.L.; Paupitz, J.; Aikawa, N.E.; Takayama, L.; Bonfa, E.; Pereira, R.M. Vitamin D Supplementation in Adolescents and Young Adults With Juvenile Systemic Lupus Erythematosus for Improvement in Disease Activity and Fatigue Scores: A Randomized Double-Blind Placebo-Controlled Trial. Arthritis Care Res. Hoboken 2016, 68, 91-98. [CrossRef] [PubMed]

20. Lima, G.L.; Paupitz, J.A.; Aikawa, N.E.; Alvarenga, J.C.; Pereira, R.M.R. A randomized double-blind placebo-controlled trial of vitamin D supplementation in juvenile-onset systemic lupus erythematosus: Positive effect on trabecular microarchitecture using HR-pQCT. Osteoporos. Int. 2018, 29, 587-594. [CrossRef] [PubMed]

21. Tam, L.S.; Li, E.K.; Leung, V.Y.; Griffith, J.F.; Benzie, I.F.; Lim, P.L.; Whitney, B.; Lee, V.W.; Lee, K.K.; Thomas, G.N.; et al. Effects of vitamins $\mathrm{C}$ and $\mathrm{E}$ on oxidative stress markers and endothelial function in patients with systemic lupus erythematosus: A double blind; placebo controlled pilot study. J. Rheumatol. 2005, 32, 275-282. 
22. Khajehdehi, P.; Zanjaninejad, B.; Aflaki, E.; Nazarinia, M.; Azad, F.; Malekmakan, L.; Dehghanzadeh, G.R. Oral supplementation of turmeric decreases proteinuria; hematuria; and systolic blood pressure in patients suffering from relapsing or refractory lupus nephritis: A randomized and placebo-controlled study. J. Ren. Nutr. 2012, 22, 50-57. [CrossRef] [PubMed]

23. Shamekhi, Z.; Amani, R.; Habibagahi, Z.; Namjoyan, F.; Ghadiri, A.; Saki Malehi, A. A Randomized; Double-blind; Placebocontrolled Clinical Trial Examining the Effects of Green Tea Extract on Systemic Lupus Erythematosus Disease Activity and Quality of Life. Phytother. Res. 2017, 31, 1063-1071. [CrossRef]

24. Hayashi, A.P.; Solis, M.Y.; Sapienza, M.T.; Otaduy, M.C.; de Sá Pinto, A.L.; Silva, C.A.; Sallum, A.M.; Pereira, R.M.; Gualano, B. Efficacy and safety of creatine supplementation in childhood-onset systemic lupus erythematosus: A randomized, double-blind, placebo-controlled, crossover trial. Lupus 2014, 23, 1500-1511. [CrossRef] [PubMed]

25. Benvenuti, F.; Gatto, M.; Larosa, M.; Iaccarino, L.; Punzi, L.; Doria, A. Cardiovascular risk factors; burden of disease and preventive strategies in patients with systemic lupus erythematosus: A literature review. Expert Opin. Drug Saf. 2015, 14, 1373-1385. [CrossRef]

26. Oliviero, F.; Scanu, A.; Zamudio-Cuevas, Y.; Punzi, L.; Spinella, P. Anti-inflammatory effects of polyphenols in arthritis. J. Sci. Food Agric. 2018, 98, 1653-1659. [CrossRef] [PubMed]

27. Oliviero, F.; Galozzi, P.; Scanu, A.; Galuppini, F.; Lazzarin, V.; Brocco, S.; Ravagnan, G.; Sfriso, P.; Ramonda, R.; Spinella, P.; et al. Polydatin Prevents Calcium Pyrophosphate Crystal-Induced Arthritis in Mice. Nutrients 2021, 13, 929. [CrossRef] [PubMed]

28. Khan, H.; Sureda, A.; Belwal, T.; Çetinkaya, S.; Süntar, I.; Tejada, S.; Devkota, H.P.; Ullah, H.; Aschner, M. Polyphenols in the treatment of autoimmune diseases. Autoimmun. Rev. 2019, 18, 647-657. [CrossRef]

29. Di Meo, F.; Valentino, A.; Petillo, O.; Peluso, G.; Filosa, S.; Crispi, S. Bioactive Polyphenols and Neuromodulation: Molecular Mechanisms in Neurodegeneration. Int. J. Mol. Sci. 2020, 21, 2564. [CrossRef]

30. Santos, S.A.; Silva, E.T.; Caris, A.V.; Lira, F.S.; Tufik, S.; Dos Santos, R.V. Vitamin E supplementation inhibits muscle damage and inflammation after moderate exercise in hypoxia. J. Hum. Nutr. Diet. 2016, 29, 516-522. [CrossRef] [PubMed]

31. Lambert, K.; Coisy-Quivy, M.; Bisbal, C.; Sirvent, P.; Hugon, G.; Mercier, J.; Avignon, A.; Sultan, A. Grape polyphenols supplementation reduces muscle atrophy in a mouse model of chronic inflammation. Nutrition 2015, 31, 1275-1283. [CrossRef]

32. Capel, F.; Acquaviva, C.; Pitois, E.; Laillet, B.; Rigaudière, J.P.; Jouve, C.; Pouyet, C.; Gladine, C.; Comte, B.; Vianey Saban, C.; et al. DHA at nutritional doses restores insulin sensitivity in skeletal muscle by preventing lipotoxicity and inflammation. J. Nutr. Biochem. 2015, 26, 949-959. [CrossRef]

33. Falcini, F.; Porfirio, B.; Lionetti, P. Juvenile dermatomyositis and celiac disease. J. Rheumatol. 1999, 26, 1419-1420. [PubMed]

34. Song, M.S.; Farber, D.; Bitton, A.; Jass, J.; Singer, M.; Karpati, G. Dermatomyositis associated with celiac disease: Response to a gluten-free diet. Can. J. Gastroenterol. 2006, 20, 433-435. [CrossRef] [PubMed]

35. Chung, Y.L.; Alexanderson, H.; Pipitone, N.; Morrison, C.; Dastmalchi, M.; Ståhl-Hallengren, C.; Richards, S.; Thomas, E.L.; Hamilton, G.; Bell, J.D.; et al. Creatine supplements in patients with idiopathic inflammatory myopathies who are clinically weak after conventional pharmacologic treatment: Six-month; double-blind; randomized; placebo-controlled trial. Arthritis Rheum. 2007, 57, 694-702. [CrossRef] [PubMed]

36. Chung, Y.L.; Rider, L.G.; Bell, J.D.; Summers, R.M.; Zemel, L.S.; Rennebohm, R.M.; Passo, M.H.; Hicks, J.; Miller, F.W.; Scott, D.L. Muscle metabolites; detected in urine by proton spectroscopy; correlate with disease damage in juvenile idiopat hic inflammatory myopathies. Arthritis Rheum. 2005, 53, 565-570. [CrossRef]

37. Solis, M.Y.; Hayashi, A.P.; Artioli, G.G.; Roschel, H.; Sapienza, M.T.; Otaduy, M.C.; De Sã Pinto, A.L.; Silva, C.A.; Sallum, A.M.; Pereira, R.M.; et al. Efficacy and safety of creatine supplementation in juvenile dermatomyositis: A randomized; double-blind; placebo-controlled crossover trial. Muscle Nerve 2016, 53, 58-66. [CrossRef]

38. Dover, S.; Stephens, S.; Schneiderman, J.E.; Pullenayegum, E.; Wells, G.D.; Levy, D.M.; Marcuz, J.A.; Whitney, K.; Schulze, A.; Tein, I.; et al. The Effect of Creatine Supplementation on Muscle Function in Childhood Myositis: A Randomized; Double-blind; Placebo-controlled Feasibility Study. J. Rheumatol. 2021, 48, 434-441. [CrossRef]

39. Consolandi, C.; Turroni, S.; Emmi, G.; Severgnini, M.; Fiori, J.; Peano, C.; Biagi, E.; Grassi, A.; Rampelli, S.; Silvestri, E.; et al. Behçet's syndrome patients exhibit specific microbiome signature. Autoimmun. Rev. 2015, 14, 269-276. [CrossRef] [PubMed]

40. Kau, A.L.; Ahern, P.P.; Griffin, N.W.; Goodman, A.L.; Gordon, J.I. Human nutrition; the gut microbiome and the immune system. Nature 2021, 474, 327-336. [CrossRef] [PubMed]

41. Pagliai, G.; Dinu, M.; Fiorillo, C.; Becatti, M.; Turroni, S.; Emmi, G.; Sofi, F. Modulation of gut microbiota through nutritional interventions in Behçet's syndrome patients (the MAMBA study): Study protocol for a randomized controlled trial. Trials 2020, 21, 511. [CrossRef]

42. Emmi, G.; Bettiol, A.; Niccolai, E.; Ramazzotti, M.; Amedei, A.; Pagliai, G.; Taddei, N.; Sofi, F.; Fiorillo, C.; Prisco, D.; et al. Butyrate-Rich Diets Improve Redox Status and Fibrin Lysis in Behçet's Syndrome. Circ. Res. 2021, 128, 278-280. [CrossRef] [PubMed]

43. Machowicz, A.; Hall, I.; de Pablo, P.; Rauz, S.; Richards, A.; Higham, J.; Poveda-Gallego, A.; Imamura, F.; Bowman, S.J.; Barone, F.; et al. Mediterranean diet and risk of Sjögren's syndrome. Clin. Exp. Rheumatol. 2020, 38 (Suppl. S126), 216-221. [PubMed]

44. Haupt-Jorgensen, M.; Groule, V.; Reibel, J.; Buschard, K.; Pedersen, A.M.L. Gluten-free diet modulates inflammation in salivary glands and pancreatic islets. Oral Dis. 2021. [CrossRef] [PubMed]

45. Tovar, A.R.; Gómez, E.; Bourges, H.; Ortíz, V.; Kraus, A.; Torres, N. Biochemical deficiency of pyridoxine does not affect interleukin-2 production of lymphocytes from patients with Sjögren's syndrome. Eur. J. Clin. Nutr. 2002, 56, 1087-1093. [CrossRef] [PubMed] 
46. Singh, M.; Stark, P.C.; Palmer, C.A.; Gilbard, J.P.; Papas, A.S. Effect of omega-3 and vitamin E supplementation on dry mouth in patients with Sjögren's syndrome. Spec. Care Dent. 2010, 30, 225-229. [CrossRef] [PubMed]

47. Codullo, V.; Cereda, E.; Klers, Y.C.; Cavazzana, I.; Alpini, C.; Bonardi, C.; Turri, A.; Franceschini, F.; Caccialanza, R.; Montecucco, C.; et al. Serum prealbumin is an independent predictor of mortality in systemic sclerosis outpatients. Rheumatol. Oxf. 2016, 55, 315-319. [CrossRef] [PubMed]

48. Sakkas, L.I.; Simopoulou, T.; Daoussis, D.; Liossis, S.N.; Potamianos, S. Intestinal Involvement in Systemic Sclerosis: A Clinical Review. Dig. Dis. Sci. 2018, 63, 834-844. [CrossRef] [PubMed]

49. Marighela, T.F.; Arismendi, M.I.; Marvulle, V.; Brunialti, M.K.C.; Salomão, R.; Kayser, C. Effect of probiotics on gastrointestinal symptoms and immune parameters in systemic sclerosis: A randomized placebo-controlled trial. Rheumatol. Oxf. 2019, 58, 1985-1990. [CrossRef] [PubMed]

50. Low, A.H.L.; Teng, G.G.; Pettersson, S.; de Sessions, P.F.; Ho, E.X.P.; Fan, Q.; Chug, C.W.; Lawa, A.H.N.; Santosacd, A.; Lim, A.Y.N.; et al. A double-blind randomized placebo-controlled trial of probiotics in systemic sclerosis associated gastrointestinal disease. Semin. Arthritis Rheum. 2019, 49, 411-419. [CrossRef] [PubMed]

51. DiGiacomo, R.A.; Kremer, J.M.; Shah, D.M. Fish-oil dietary supplementation in patients with Raynaud's phenomenon: A double-blind; controlled; prospective study. Am. J. Med. 1989, 86, 158-164. [CrossRef] 